University of Florida Levin College of Law

UF Law Scholarship Repository

2014

\title{
The Transformation Of Vertical Restraints: Per Se Illegality, The Rule Of Reason, And Per Se Legality
}

D. Daniel Sokol

University of Florida Levin College of Law, sokold@law.ufl.edu

Follow this and additional works at: https://scholarship.law.ufl.edu/facultypub

Part of the Antitrust and Trade Regulation Commons

\section{Recommended Citation}

D. Daniel Sokol, The Transformation Of Vertical Restraints: Per Se Illegality, The Rule Of Reason, And Per Se Legality, 79 Antitrust L.J. 1003 (2014), available at http://scholarship.law.ufl.edu/facultypub/546

This Article is brought to you for free and open access by the Faculty Scholarship at UF Law Scholarship Repository. It has been accepted for inclusion in UF Law Faculty Publications by an authorized administrator of UF Law Scholarship Repository. For more information, please contact kaleita@law.ufl.edu. 


\title{
THE TRANSFORMATION OF VERTICAL RESTRAINTS: PER SE ILLEGALITY, THE RULE OF REASON, AND PER SE LEGALITY
}

\author{
D. DANIEL SOKOL*
}

Robert Bork probably had the single most lasting influence on antitrust law and policy of anyone in the past 50 years. ${ }^{1}$ To read the 1978 Antitrust Para$d o x^{2}$ today, one is struck by how closely contemporary case law tracks Bork's policy prescriptions. ${ }^{3}$ The speed at which the transformation in law and policy occurred in antitrust is perhaps unprecedented across any area of common law. ${ }^{4}$ In the 1970s, antitrust jurisprudence and enforcement policies were in

* Professor, University of Florida Levin College of Law; Senior Research Fellow, George Washington University Law School Competition Law Center. I wish to thank Lee Greenfield, Josh Soven, and conference participants at Yale Law School for their feedback, as well as the University of Florida for a summer research grant.

${ }^{1}$ The tension of the then competing goals of antitrust-promoting efficiency and protecting smaller firms - in academic and policy circles shaped Bork's writing and advocacy. Bork believed that the Supreme Court (and implicitly lower courts) showed hostility to business and that this approach to antitrust law needed to change. $C f$. Robert H. Bork, Vertical Restraints: Schwinn Overruled, 1977 Sup. CT. Rev. 171, 172 [hereinafter Bork, Vertical Restraints].

2 Robert H. Bork, The Antitrust Paradox: A Policy at War with Itself (1978) [hereinafter Bork, Antitrust Paradox].

${ }^{3}$ For a recent overview of the state of the antitrust economics literature, see generally $\mathrm{Ox}$ FORd Handbook of International Antitrust Economics (Roger D. Blair \& D. Daniel Sokol eds., forthcoming 2014). Bork's understanding of economics needs to be judged by what was known both theoretically and empirically at the time he wrote since there have been significant developments in antitrust economics since the publication of The Antitrust Paradox. Bork's understanding of antitrust came from Chicago scholarship of Ward S. Bowman, Jr. , The Prerequisites and Effects of Resale Price Maintenance, 22 U. CHI. L. REv. 825 (1955); Aaron Director \& Edward H. Levi, Law and the Future: Trade Regulation, 51 Nw. U. L. Rev. 281 (1956); John S. McGee, Predatory Price Cutting: The Standard Oil (N.J.) Case, 1 J.L. \& Econ. 137 (1958); George J. Stigler, A Theory of Oligopoly, 72 J. PoL. Econ. 44 (1964); Lester G. Telser, Why Should Manufacturers Want Fair Trade?, 3 J.L. \& Econ. 86 (1960). The Chicago approach stood in contrast to some contemporaries. See, e.g., Louis B. Schwartz, "Justice” and other NonEconomic Goals of Antitrust, 127 U. PA. L. Rev. 1076 (1979); Milton Handler, Antitrust in Perspective: The Complementary Roles of Rule and Discretion (1957).

4 The closest similar shift was in the area of government regulation where, starting in the late 1970s, there was a shift from price regulation to market-based regulation. See generally BARAK Y. Orbach, Regulation: Why and How the State Regulates (2012).

1003

79 Antitrust Law Journal No. 3 (2014). Copyright 2014 American Bar Association. Reproduced by permission. All rights reserved. This information or any portion thereof may not be copied or disseminated in any form or by any means or downloaded or stored in an electronic database or retrieval system without the express written consent of the American Bar Association. 
tension with industrial organization economics. Bork created a unified goal for antitrust based on a "consumer welfare prescription" to shape the development of the case law..$^{5}$ The shaping of U.S. antitrust law to fit Bork's consumer welfare prescription is all the more interesting given that although Bork was not the first to argue that antitrust analysis should focus on industrial organization based economic analysis, he was the first to package these beliefs in an easy-to-understand manner that the courts could implement. ${ }^{6}$ While many of Bork's ideas are mainstream now, at the time of publication his writing was highly contentious and the notion of an economics-based consumerwelfare antitrust standard was very controversial.

This essay describes Bork's policy objectives for the antitrust treatment of vertical restraints, explains why Bork had such a disproportionate influence on the subject, and tracks Bork's influence on the development of vertical restraints in three specific areas: maximum resale price maintenance (RPM); vertical territorial restrictions; and Robinson-Patman Act violations. In practice, the shift in the antitrust rules applied to these areas has not been from per se illegality to the rule of reason, but has been a more dramatic shift from per se illegality to presumptive legality under the rule of reason. ${ }^{7}$

\section{BORK AS THE CATALYST FOR ANTITRUST'S SHIFT ON VERTICAL RESTRAINTS}

\section{A. Bork's Antitrust Prescription Regarding Vertical Restraints}

Bork differed from the other antitrust reformers in his approach to vertical restraints. In his seminal article, The Rule of Reason and the Per Se Concept: Price Fixing and Market Division Part II, Bork advocated for per se legality for vertical restraints. ${ }^{8}$ He reiterated this call for per se legality for vertical

5 Bork, Antitrust Paradox, supra note 2, at 66.

${ }^{6}$ Bork had a greater effect on the development of antitrust law than his Chicago contemporaries who used economic analysis, even though Bork's work was less economically sophisticated. Compare the impact of Richard A. Posner's Antitrust Law: An Economic Perspective (1976) with The Antitrust Paradox.

7 The three areas studied are unlike more complex vertical restraints such as exclusive dealing, tying, and certain pricing practices (e.g., bundling and loyalty discounts). The three vertical restraints selected tend not to require the difficult balancing of efficiencies versus potential to exclude as much as other vertical restraints, which makes the latter more challenging to analyze. Hence, these three areas are those that are most likely to be able to shift to per se legality in practice.

${ }^{8}$ Robert H. Bork, The Rule of Reason and the Per Se Concept: Price Fixing and Market Division-Part II, 75 Yale L.J. 373, 391 (1966) (“[A]ll vertical market division and price fixing should be lawful regardless of the parties' market size."); see also Bork, Vertical Restraints, supra note 1, at 173 ("[V]ertical restraints are, in economic terms, all of a piece. There are no distinctions to be made among them. They should be either all illegal per se or unqualified lawful. But legal doctrine is not in line with economic reality . . .."); id. at 182. 
restraints in The Antitrust Paradox. ${ }^{9}$ In contrast, most others advocating reform of the treatment of vertical restraints favored applying the rule of reason and believed that certain vertical conduct violated the antitrust laws. ${ }^{10}$

Bork's vision for per se legality for vertical restraints has been realized, at least partially. For several types of vertical restraints, the rule of reason has in practice meant near per se legality, with a negative safe harbor for particularly egregious behavior.

\section{B. Bork and the Efficiency of the Common Law of Antitrust}

Bork's advocacy of his approach to how to "fix" antitrust connects to the concept of the efficiency of the common law. Richard Posner was the first to

\footnotetext{
${ }^{9}$ Bork, Antitrust Paradox, supra note 2, at 288 ("Analysis shows that every vertical restraint should be completely lawful."). Bork advocated this approach earlier than Easterbrook or Posner. See Richard A. Posner, The Next Step in the Antitrust Treatment of Restricted Distribution: Per Se Legality, 48 U. CHI. L. Rev. 6 (1981); Frank H. Easterbrook, Vertical Arrangements and the Rule of Reason, 53 ANTITRUST L.J. 135, 158 (1984).
}

Bork was a bit disingenuous in stating that he was against all vertical restraints. Bork believed that Lorain Journal was correctly decided. Lorain Journal Co. v. United States, 342 U.S. 143 (1951); Bork, Antitrust Paradox, supra, at 344-46. In that case, the monopolist daily newspaper in the town of Lorain, Ohio, refused ads by advertisers who also placed ads with Lorain Journal's only other potential media rivals, the local radio stations. The Supreme Court held that "forcing advertisers to boycott a competing radio station violated $\S 2$." Lorain Journal, 342 U.S. at 152. For Bork, Lorain Journal's intent was predatory, as it wanted to bankrupt the radio stations and gain their FCC licenses. He also noted that there was no efficiency justification for Lorain Journal's behavior. Bork, Antitrust PARAdox, supra, at 345.

Even after the publication of The Antitrust Paradox, Bork found similar situations that had vertical elements that raised legitimate antitrust concern. The key to understanding why certain vertical behavior still deserved antitrust scrutiny and not automatic per se legal condemnation had to do with efficiencies. Bork was critical in the exclusive dealing context of the Supreme Court's "excessively harsh" treatment (e.g., Standard Fashion Co. v. Magrane-Houston Co., 258 U.S. 346 (1922); United States v. Griffith; 334 U.S. 100 (1948); FTC v. Motion Picture Advertising Serv. Co., 344 U.S. 392 (1953)) because the Court's understanding of foreclosure arguments gave insufficient (if any) weight to efficiencies. Bork, ANTITRUst PARADOx, supra, at 304-08. Specifically, Bork argued, "The advantage of the contract must be the creation of efficiency, and [there are] a variety of efficiencies that such contracts may create." Id. at 304-05.

Bork found Microsoft's behavior troubling from an antitrust perspective in terms of exclusion. In the DOJ case against Microsoft, the troubling behavior was that Microsoft required that original equipment manufacturers, vendors of software, and Internet service providers exclusively carry Microsoft's Internet Explorer. Bork likened Microsoft's behavior to that of Lorain Journal, arguing that Microsoft was a monopolist that lacked an efficiency justification for its exclusionary conduct. Robert Bork, Op-Ed, What Antitrust Is All About, N.Y. Times, May 4, 1998, at A19. Though Microsoft tried to hire Bork, Bork consulted for Netscape in the case. Harry First, Bork and Microsoft: Why Bork Was Right and What We Learn About Judging Exclusionary Behavior, infra this issue, 79 AnTitrust L.J. 1017, 1019 n.7 (2014).

10 See, e.g., Posner, Antitrust Law, supra note 6, at 171 ("Some economists believe that it is virtually impossible for a firm or group of firms ever to exclude competitors or potential competitors from the market unless they have lower costs. . . . I do not share this view."). 
hypothesize that the common law led to more efficient legal rules. ${ }^{11}$ The explanation for the efficiency of the common law is that when a judge makes an incorrect ruling, an economically disadvantaged party will challenge the rule because the disadvantage is greater than the advantage to the beneficiary of the rule. Antitrust, which is a broad statutory regime governed by common law, fits within the efficiency of the common law paradigm. ${ }^{12}$ As a result, with advances in economic knowledge, antitrust law shifts to more efficient legal rules over time, as disadvantaged parties challenge inefficient rules and use economic analysis to change them. ${ }^{13}$

Antitrust jurisprudence and economic analysis in the 1950s and 1960s was hostile to procompetitive interpretations of vertical restraints. ${ }^{14}$ Starting with Donald Turner, some have called this antitrust's "inhospitality tradition." 15 Bork's contribution to transforming antitrust's inhospitality tradition was to increase the shift to more efficient rules, especially in those areas of greatest inefficiency of legal rules (maximum RPM, territorial restrictions, and Robinson-Patman).

Bork was successful in transforming antitrust, relative to Posner and other antitrust reformers of the era, because Bork promised that, through the use of

11 Richard A. Posner, Economic Analysis of Law (1st ed. 1972); see also Paul Rubin, Why Is the Common Law Efficient?, 6 J. LEGAL STUd. 51 (1977) (formally modeling the efficiency of the common law).

12 See William F. Baxter, Separation of Powers, Prosecutorial Discretion, and the "Common Law" Nature of Antitrust Law, 60 Tex. L. Rev. 661, 663 (1982); William H. Page, The Chicago School and the Evolution of Antitrust: Characterization, Antitrust Injury, and Evidentiary Sufficiency, 75 VA. L. REv. 1221, 1226-27 (1989).

13 Of course, the change is not instant and so one might question how efficient the common law is if there is a long enough lag time.

${ }^{14}$ Herbert J. Hovenkamp, Robert Bork and Vertical Integration: Leverage, Foreclosure, and Efficiency, supra this issue, 79 AnTitrust L.J. 983, 988 (2014) ("While Bork exaggerated the degree of hostility toward vertical integration prior to the 1930 s, by the time he was writing in the 1950s, both the economic theory and the law had become far more critical . . ..").

${ }^{15}$ Alan J. Meese, Market Power and Contract Formation: How Outmoded Economic Theory Still Distorts Antitrust Doctrine, 88 Notre Dame L. Rev. 1291, 1322 \& n.124 (2013). The original citation is to Turner's speech to the Antitrust Section of the New York State Bar Association in which Turner said, "I approach customer and territorial restrictions not hospitably in the common law tradition, but inhospitably in the tradition of antitrust." Oliver E. Williamson, Mergers, Acquisitions and Leveraged Buyouts: An Efficiency Assessment, in Corporate LAw AND Economic Analysis 1, 21 n.24 (Lucian Arye Bebchuk ed., 1990) (citing Stanley Robinson, N.Y. State Bar Association Antitrust Symposium 1968 at 29.). 
simple rules ${ }^{16}$ and a straightforward singular goal of antitrust, ${ }^{17}$ antitrust doctrine and practice could be improved. ${ }^{18}$ He did so through a clear and accessible writing style that fused Harvard School considerations of administrability and legal process with Chicago School economic-based analysis ${ }^{19}$ - a factor that made it possible for judges to easily process and apply Bork's writing. The mix of the two traditions promoted the case law shift. ${ }^{20}$

Bork's writing was brilliant in using clear prose ${ }^{21}$ to make points that were sometimes analytically deceptive. Bork convincingly made the seemingly counterintuitive case that abandoning per se illegality for the rule of reason would simplify antitrust. Bork understood that, in practice, the push to rule of reason would actually lead to presumptive or even per se legality. Because the details of particular practices matter for a rule of reason analysis, the shift to rule of reason creates various evidentiary hurdles for plaintiffs and increases the cost of litigation. The use of the rule of reason would thereby serve as a

${ }^{16}$ Bork, Antitrust Paradox, supra note 2, at 72 ("The need of the law generally is for the systematic development of normative models of judicial behavior, models which, while they cannot attain, will at least distantly approach the rigor of the descriptive models of basic economic theory. Until we have such models, criticism of the courts for having the wrong goals will generally be empty, the mere assertion of a different set of personal preferences.").

${ }^{17}$ Id. at 7, 50; Robert Bork, Antitrust and Monopoly: The Goals of Antitrust Policy, 57 Ам. Econ. Rev. (PAPers \& Proc.) 242 (1967); Robert H. Bork, Legislative Intent and the Policy of the Sherman Act, 9 J.L. \& ECON. 7 (1966).

${ }^{18}$ In fact, economic analysis of antitrust is not simple nor was there ever a single goal. See, e.g., Roger D. Blair \& D. Daniel Sokol, Welfare Standards in U.S. and E.U. Antitrust Enforcement, 81 Fordham L. Rev. 2497 (2013); Herbert Hovenkamp, Implementing Antitrust's Welfare Goals, 81 Fordham L. Rev. 2471 (2013); John B. Kirkwood \& Robert H. Lande, The Fundamental Goal of Antitrust: Protecting Consumers, Not Increasing Efficiency, 84 Notre Dame L. REv. 191 (2008). Bork wrote that the sole goal of antitrust was consumer welfare, largely because "consumer" was an easier sell to a broader audience in terms of the goal (as the 1960s and 1970s saw the birth of the consumer movement). However, by consumer welfare, Bork meant total welfare. See Bork, Antitrust Paradox, supra note 2, at 91. For a discussion of the meaning of Bork and goals of antitrust, see Barak Y. Orbach, The Antitrust Consumer Welfare Paradox, 7 J. Competition L. \& Econ. 133 (2011). Bork merely appropriated the word consumer because it was easier for courts to understand this concept. Many courts, including the Supreme Court, continue to confuse consumer and total welfare in their antitrust jurisprudence. Roger D. Blair \& D. Daniel Sokol, The Rule of Reason and the Goals of Antitrust: An Economic Approach, 78 Antitrust L.J. 471, 473 (2012). For an analysis of the shift in the rule of reason, see Andrew I. Gavil, Moving Beyond Caricature and Characterization: The Modern Rule of Reason in Practice, 85 S. CAL. L. Rev. 733 (2012).

${ }^{19}$ See Thomas C. Arthur, The Influence of Levi's Legal Process on Bork's Antitrust Paradox, 17 Miss. C. L. Rev. 124 (1996); James May, Redirecting the Future: Law and the Future and the Seeds of Change in Modern Antitrust Law, 17 Miss. C. L. Rev. 43, 73-78 (1996).

${ }^{20}$ William E. Kovacic, The Intellectual DNA of Modern U. S. Competition Law for Dominant Firm Behavior: The Chicago/Harvard Double Helix, 2007 Colum. Bus. L. Rev. 1, 14 (2007).

${ }^{21}$ Many theorists in the economics tradition lacked Bork's prose or his almost religious fervor for the correctness of his position. See, e.g., Bork, Antitrust PARAdox, supra note 2, at 285 ("Antitrust is capable of sustaining meaningless distinctions and sterile paradoxes, but those of Schwinn were too many and too obvious to persist for long."); id. at 382 ("[The RobinsonPatman Act is] the misshapen progeny of intolerable draftsmanship coupled with wholly mistaken economic theory."). 
screen to weed out weaker cases in which there was an efficiency justification for the restraint.

Bork also benefited from good timing: his influence is partially attributable to the publication date of The Antitrust Paradox. The book was mostly ready for publication by 1969, but it was delayed because of the illness of Bork's first wife and his appointment as Solicitor General. As a result, the book was published in 1978, just as the Chicago shift began in the Supreme Court. Bork's position as Solicitor General allowed the Supreme Court to get to know Bork well, which likely gave Bork's writing greater credence. ${ }^{22}$ It also allowed Bork to train and influence many of the attorneys who would argue before the Supreme Court for the next generation.

Bork's policy prescriptions became part of formal government policy starting in the Reagan administration. ${ }^{23}$ This led to a significant decline in federal enforcement against vertical restraints. Government challenges to vertical practices (and civil non-merger cases in general) have never recovered to preReagan levels. ${ }^{24}$

\section{STRUCTURAL SHIFTS IN THE CASE LAW ON VERTICAL RESTRAINTS}

The Chicago School's impact on vertical restraints and business behavior was uneven. Certain types of conduct, such as exclusive dealing, continued to receive significant scrutiny. But in three areas-maximum RPM, non-price restraints, and Robinson-Patman Act violations, Bork's writing (and advocacy in front of the Supreme Court in the case of Robinson-Patman) helped cause the case law to push aside per se illegality rules in favor of de facto per se legality. The result was more aggressive vertical behavior by businesses, as they realized that there was little legal risk to conduct that previously had been per se unlawful. ${ }^{25}$

${ }^{22}$ George L. Priest, Bork's Strategy: Price Fixing, and the Influence of the Chicago School on Modern Antitrust Law, 57 J.L. \& ECON (forthcoming 2014), available at papers.ssrn.com/sol3/ papers.cfm?abstract_id=2367028.

${ }^{23}$ See Vivek Ghosal, Regime Shift in Antitrust Laws, Economics and Enforcement, 7 J. ComPETITION L. \& ECON. 733, 736 (2011).

${ }^{24} I d$.

25 This suggests Bork's work has had even more influence than is reflected in the case law alone. However, direct demonstrations of these changes are difficult. Consequently, this essay identifies Bork's influence on possible correlations between shifts in business behavior and shifts in case law by examining the empirical work on vertical contracting specific to the doctrinal shifts discussed. 


\section{A. Maximum Resale Price Maintenance}

The origins of per se illegality for maximum RPM emerged from Socony Vacuum..$^{26}$ In that case, Justice Douglas created an expansive per se rule that prohibited "raising, depressing, fixing, pegging, or stabilizing the price of a commodity in interstate or foreign commerce." 27 The Supreme Court reaffirmed the per se prohibition through dicta in Kiefer-Stewart, which involved liquor dealers and maximum prices. ${ }^{28}$

These cases served as precursors to one of the worst antitrust decisions of the past 50 years. In 1968, the Supreme Court held maximum RPM to be per se illegal in Albrecht v. Herald Co. ${ }^{29}$ The Court reasoned that suppliers may choose the wrong price. ${ }^{30}$ The Court also showed concern that maximum RPM could easily become a minimum price and lead to collusion. ${ }^{31}$

Case law began to chip away at the Albrecht per se rule in Atlantic Richfield Co. v. USA Petroleum Co. (ARCO). ${ }^{32}$ In its ARCO decision, the Court did not overturn Albrecht, ${ }^{33}$ but noted that it might be willing to overturn Albrecht if the question were to come before it. ${ }^{34}$ In doing so, the Court noted the scholarship of Bork and others that was critical of per se rules for maximum RPM. $^{35}$

In State Oil Co. v. Khan, ${ }^{36}$ the Supreme Court did overturn Albrecht, and made maximum RPM subject to the rule of reason. The Supreme Court found that the maximum profit margin agreement should not have been held per se illegal. In doing so, it relied on Bork's analysis of Albrecht and cited The Antitrust Paradox for the proposition that " $[\mathrm{t}]$ here could, of course, be no anticonsumer effect from [the type of price fixing considered in Albrecht], and one suspects that the paper has a legitimate interest in keeping subscriber

\footnotetext{
${ }^{26}$ United States v. Socony-Vacuum Oil Co., 310 U.S. 150 (1940).

${ }^{27} I d$. at 223.

${ }^{28}$ Kiefer-Stewart Co. v. Joseph E. Seagram \& Sons, Inc., 340 U.S. 211, 213 (1951) ("[Maxi-
} mum RPM may] cripple the freedom of traders and thereby restrict their ability to sell in accordance with their own judgment."), overruled on other grounds by Copperweld Corp. v. Independence Tube Corp., 467 U.S. 752 (1984).

29390 U.S. 145 (1968), overruled by State Oil Co. v. Khan, 522 U.S. 3 (1997). The reasoning behind the Albrecht decision was flawed. See Roger D. Blair \& John E. Lopatka, The Albrecht Rule After Khan: Death Becomes Her, 74 Notre Dame L. Rev. 123 (1998); Frank H. Easterbrook, Maximum Price Fixing, 48 U. CHI. L. Rev. 886 (1981).

${ }^{30}$ Albrecht, 390 U.S. at 152.

${ }^{31}$ Id. at 153.

32495 U.S. 328 (1990).

${ }^{33} \mathrm{Id}$. at 335 n. 5 .

${ }^{34} I d$. at 343 n. 15.

${ }^{35}$ Id.

36522 U.S. 3 (1997). 
prices down in order to increase circulation and maximize revenues from advertising." 37

Since State Oil, there is little antitrust risk in implementing maximum RPM. There have been over 225 federal decided antitrust keycited cases that have cited State Oil. ${ }^{38}$ Of these, nearly all citations to State Oil are for the broad proposition that State Oil stands for the applicability of the rule of reason. Only six cases dealt with actual claims of maximum RPM. Four cases were decided in favor of the defendant based on the facts and two on antitrust injury grounds. No cases have held for the plaintiff. ${ }^{39}$

\section{B. Non-Price Vertical Restrictions}

Early vertical non-price case law made economic sense. In White Motor Co. v. United States ${ }^{40}$ the "first case involving a territorial restriction in a vertical arrangement," ${ }_{41}$ the Supreme Court applied the rule of reason to exclusive territories that a manufacturer assigned to its distributors and dealers. The Court stated that it applied the rule of reason because "[w]e do not know enough of the economic and business stuff out of which these arrangements emerge to be certain." 42

This victory for economic sense was short-lived. Only four years later, in United States v. Arnold, Schwinn \& Co. ${ }^{43}$ the Court revisited whether vertical non-price restraints should be analyzed as per se unlawful or under the rule of reason. The Court held the territorial restrictions per se illegal based on the rationale that they impeded the economic viability of small (and often inefficient) businesses. ${ }^{44}$ Bork's harsh response was that "Schwinn's result was not only wrong, but its rationale verged on mere wittiness." 45

${ }^{37} \mathrm{Id}$. at 16.

38 The results come from a Westlaw search conducted in August 2013.

39 The paucity of cases suggests that maximum RPM cases never should have been per se illegal. That some cases were decided on antitrust injury grounds provides evidence to support the theoretical claim made first by Blair and Lang in 1991 (before State Oil) that "[i]t is readily apparent that the victim of maximum resale price fixing has not suffered antitrust injury." Roger D. Blair \& Gordon L. Lang, Albrecht After ARCO: Maximum Resale Price Fixing Moves Toward the Rule of Reason, 44 VAND. L. REv. 1007, 1021 (1991).

40372 U.S. 253 (1963).

${ }^{41} I d$. at 261 .

42 Id. at 263.

43388 U.S. 365 (1967), overruled by Continental T.V., Inc. v. GTE Sylvania Inc., 433 U.S. 36 (1977).

${ }^{44} I d$. at 382 ("Once the manufacturer has parted with title and risk, he has parted with dominion over the product, and his effort thereafter to restrict territory or persons to whom the product may be transferred-whether by explicit agreement or by silent combination or understanding with his vendee-is a per se violation of $\S 1$ of the Sherman Act.").

${ }^{45}$ Bork, Vertical Restraints, supra note 1, at 172. 
A decade later, the Supreme Court overturned Schwinn in Continental T.V., Inc. v. GTE Sylvania Inc. ${ }^{46}$ The Court held that non-price restrictions would be analyzed under the rule of reason. In doing so, the Sylvania Court relied heavily on Bork (five citations to his work) to recognize that non-price restrictions enhanced interbrand competition from manufacturer efficiencies created by vertical restraints. ${ }^{47}$

Sylvania specifically addressed territorial restrictions, but it also signaled a broad shift across all of antitrust to the use of the rule of reason instead of per se illegality for conduct that did not involve horizontal price agreements. Bork made just such an argument shortly after Sylvania. He explained:

Sylvania holds the promise of fundamental reform, not only in the law of vertical restraints but in antitrust generally. The present misshapen look of antitrust doctrine is due in large measure to the Supreme Court's habit of regarding business efficiency as either irrelevant or harmful. ... The Court's Sylvania opinion not only counted efficiencies in favor of a challenged business practice but did so in a sophisticated way, perceiving that the elimination or mitigation of competition among a manufacturer's dealers was essential to the achievement of certain distributional efficiencies. Moreover, in resting its decision on those grounds, the Court necessarily accepted the premise that the antitrust laws are, primarily if not solely, concerned with consumer welfare. ${ }^{48}$

In an analysis of cases decided through 1991, Judge Douglas Ginsburg examined all federal appellate decisions that cited Sylvania on the merits. He found that defendants succeeded more than 90 percent of the time. ${ }^{49}$ Ginsburg concluded that the law had moved to de facto per se legality where the conduct of a monopolist is not at issue. This work has not been updated in a manner that breaks down cases in the same way, although Michael Carrier finds that in 84 percent of all rule of reason cases (1977-1999), the plaintiff cannot show an anticompetitive effect; ${ }^{50}$ likewise, in the following 20 years

46433 U.S. 36 (1977).

${ }^{47} \mathrm{Id}$. at 56, 66-69 nn.8-10. The majority cited to his work as authority as an "economist" regarding promoting intrabrand competition for efficient distribution, on the limitations of Schwinn (in the concurrence by Justice White), twice on the goal of economic efficiency in antitrust (in the concurrence by Justice White), and on how the procompetitive justifications of exclusive territories also apply in the case of RPM (in the concurrence by Justice White).

${ }^{48}$ Bork, Vertical Restraints, supra note 1, at 172. Even though Sylvania signaled an important change to a more efficient rule, in the immediate period after Sylvania its importance remained controversial in the lower courts, in part because Sylvania's market share was a mere 5 percent at the time of trial, suggesting that it lacked the market power necessary to cause anticompetitive effects. See Sylvania, 433 U.S. at 38.

${ }^{49}$ Douglas H. Ginsburg, Vertical Restraints: De Facto Legality Under the Rule of Reason, 60 Antitrust L.J. 67, 71 (1992).

${ }^{50}$ Michael A. Carrier, The Real Rule of Reason: Bridging the Disconnect, 1999 BYU L. REv. 1267, 1268; see also Shantanu Dutta et al., Vertical Territorial Restrictions and Public Policy: Theories and Industry Evidence, 63 J. MARKETING 121 (1999) (tracking business marketing and distribution decisions regarding territorial restrictions through the use of survey data to measure 
(1999-2009), the plaintiff shows no anticompetitive effect in 97 percent of rule of reason cases. ${ }^{51}$

\section{Robinson-PatMAn}

Bork described the Robinson-Patman $\mathrm{Act}^{52}$ as "antitrust's least glorious hour." 53 The Act's original name- "Wholesale Grocer's Protection Act" was an indication of its protectionist nature. ${ }^{54}$ The Supreme Court also has noted the purpose of the Act:

The legislative history of the Robinson-Patman Act makes it abundantly clear that Congress considered it to be an evil that a large buyer could secure a competitive advantage over a small buyer solely because of the large buyer's quantity purchasing ability. The Robinson-Patman Act was passed to deprive a large buyer of such advantages . . . .55

At the time Bork first wrote about vertical restraints, the antitrust agencies (and private plaintiffs) used Robinson-Patman aggressively to prevent procompetitive price discrimination. ${ }^{56}$ Case law at the time of Bork's writing was hostile to procompetitive justifications for both primary line and secondary line price discrimination. ${ }^{57}$

Bork attacked Robinson-Patman because price discrimination could be good for competition. ${ }^{58}$ Robinson-Patman denied the benefits of scale econo-

the effects of Sylvania and finding that "business efficiency considerations play a significant role in the decision to use territorial restrictions").

${ }^{51}$ Michael A. Carrier, The Rule of Reason: An Empirical Update for the 21st Century, 16 Geo. Mason L. Rev. 827, 828 (2009).

5215 U.S.C. $\S 13$.

53 Bork, Antitrust Paradox, supra note 2, at 382.

${ }^{54}$ D. Daniel Sokol, Limiting Anticompetitive Government Interventions that Benefit Special Interests, 17 Geo. Mason L. Rev. 119, 128 (2009).

55 FTC v. Morton Salt Co., 334 U.S. 37, 43 (1948).

56 Some of the criticisms of Robinson-Patman were longstanding. See, e.g., U.S. DEP'T OF Justice, Report of the Attorney General's National Committee to Study the Antitrust Laws 132 (1955) [hereinafter Attorney General's Report]; AMERICAN Bar Ass'N, Report of the Commission to Study the Federal Trade Commission 67-68 (Sept. 15, 1969); Richard Posner, The Robinson-Patman Act: Federal Regulation of Price Differences (1976); U.S. Dep't of Justice, Dep't of Justice Report on the Robinson-Patman ACT (1977). The criticism of Robinson-Patman has continued to the present. See AnTITRUST Modernization Comm'n, Report and Recommendations 317-26 (2007) (calling for repeal of the Robinson-Patman Act), available at govinfo.library.unt.edu/amc/report_recommendation/ amc_final_report.pdf.

57 The two most prevalent types of Robinson-Patman claims are primary line injury (primary because the injury to competition stems from other sellers being injured by the discriminatory discount of a seller) and secondary line injury (secondary because the injury to competition stems from seller's disfavored customers' injury vis-à-vis the favored customer of the seller).

${ }^{58}$ Bork, Antitrust Paradox, supra note 2, at 394-98; see also Herbert Hovenkamp, The Robinson-Patman Act and Competition: Unfinished Business, 68 AnTitrust L.J. 125, 143-44 (2000). 
mies to buyers. As a result, consumer prices were higher than what they would have been without the Act. ${ }^{59}$

In the pre-Antitrust Paradox era, the most important primary line Robinson-Patman case was Utah Pie,${ }^{60}$ a decision that Bork strongly criticized. ${ }^{61}$ The case alleged a coordinated pricing scheme by three large national firms against a local firm that reduced the price of pies. The Supreme Court found for the plaintiff Utah Pie, even though such an outcome favored a competitor over consumers. ${ }^{62}$ As a result of the case, inefficient competitors could defend themselves against more efficient competitors by using Robinson-Patman.

Secondary line injury cases were equally problematic. The seminal preAntitrust Paradox case in this area was Morton Salt..$^{63}$ Based on an assumption that price discrimination led to adverse competitive effects, the Supreme Court, without any showing of actual consumer harm, condemned the volume discount price discrimination used by Morton Salt. ${ }^{64}$

Brooke Group marked the end of plaintiffs' victories in primary line cases. ${ }^{65}$ Brooke Group, a small competitor, sued Brown \& Williamson under Robinson-Patman for primary-line price discrimination, alleging both discriminatory and below cost discounts. The Supreme Court held that for a plaintiff to prevail, (1) the defendant's price must be below some measure of its costs, and (2) the defendant must have a reasonable prospect of recoupment of its below-cost price losses. ${ }^{66}$ The recoupment prong eviscerated the Utah Pie standard and made it nearly impossible in practice for plaintiffs to win a primary line Robinson-Patman claim going forward. Doctrinally, the case is important because it led to a structural shift in primary line Robinson-Patman case outcomes.

\footnotetext{
${ }^{59}$ For an analysis, see Dennis W. Carlton \& Jeffrey Perloff, Modern Industrial OrGANizAtion 675 (4th ed. 2005); Roger D. Blair \& Christina DePasquale, “Antitrust's Least Glorious Hour": The Robinson-Patman Act, 57 J.L. \& Econ. (forthcoming 2014), available at sitemaker.umich.edu/depasquale/files/depasquale_jle_2014.pdf.

${ }^{60}$ Utah Pie Co. v. Cont'l Baking Co., 386 U.S. 685 (1967).

${ }^{61}$ Bork, Antitrust Paradox, supra note 2, at 387 ("There is no economic theory worthy of the name that could find an injury to competition on the facts of the case. Defendants were convicted not of injuring competition but, quite simply, of competing.").

${ }^{62}$ Utah Pie, 386 U.S. at 703 ("We believe that the Act reaches price discrimination that erodes competition as much as it does price discrimination that is intended to have immediate destructive impact. "). For an in-depth analysis, see Kenneth G. Elzinga \& Thomas F. Hogarty, Utah Pie and the Consequences of Robinson-Patman, 21 J.L. \& Econ. 427 (1978); see also Ward S. Bowman, Restraint of Trade by the Supreme Court: The Utah Pie Case, 77 YALE L.J. 70 (1967).

${ }^{63}$ FTC v. Morton Salt Co., 334 U.S. 37 (1948).

${ }^{64} \mathrm{Id}$. at $46-47$.

65 Brooke Group Ltd. v. Brown \& Williamson Tobacco Corp., 509 U.S. 209 (1993).

${ }^{66} I d$. at 222-23.
} 
Unlike primary line case outcomes, secondary line cases did not experience a significant shift until Volvo ${ }^{67}$ In Volvo, there were two core issues regarding secondary-line price discrimination. In the first, the Court held that under the Robinson-Patman Act a manufacturer was not liable for secondary-line price discrimination without a showing by plaintiffs that the manufacturer contemporaneously discriminated between dealers that competed in reselling the manufacturer's product to the identical retail customer. The Court's second holding was that the plaintiff dealer did not establish injury to competition. ${ }^{68}$ The Court, citing directly to Bork's scholarship and indirectly to Bork by relying on Sylvania, reasoned that "we would resist interpretation geared more to the protection of existing competitors than to the stimulation of competition." 69

Radical changes in the level of government enforcement activity of the Act added to the decline in private cases. Under the Kennedy and Johnson administrations, 518 Robinson-Patman cases were brought; ${ }^{70}$ in the $1965-1968$ period, the FTC undertook 97 Robinson-Patman investigations a year and issued an average of 27 complaints a year during that period. ${ }^{71}$ The Carter administration brought just eight Robinson-Patman Act cases. As a result, federal agency Robinson-Patman enforcement is dead, with only one government case brought since $1992 .{ }^{72}$ Moreover, by the mid 1970s the Department of

${ }^{67}$ Volvo Trucks N. Am., Inc. v. Reeder-Simco GMC, Inc., 546 U.S. 164 (2006).

68 "[T]here is no evidence that any favored purchaser possesses market power, the allegedly favored purchasers are dealers with little resemblance to large independent department stores or chain operations, and the supplier's selective price discounting fosters competition among suppliers of different brands. By declining to extend Robinson-Patman's governance to such cases, we continue to construe the Act 'consistently with broader policies of the antitrust laws.' "Id. (internal citation omitted). All, however, is not totally resolved regarding secondary line injury cases and it is still possible to run afoul of Robinson-Patman post-Volvo. See Barbara O. Bruckmann, Volvo Seven Years Later: Williams v. Duke Energy International, Inc., ANTITRUst Source, Feb. 2013, www.americanbar.org/content/dam/aba/publishing/antitrust_source/feb13_ bruckmann_2_26f.authcheckdam.pdf. Additional case refinement (or ideally repeal of the statute) is still required.

${ }^{69}$ Volvo Trucks, 546 U.S. at 181.

70 William E. Kovacic, Modern Evolution of U.S. Competition Policy Enforcement Norms, 71 Antitrust L.J. 377, 411 (2003). Nor was Robinson-Patman even effective at reaching its goal of helping small competitors. See F.M. Scherer \& David Ross, Industrial Market Structure and Economic Performance 516 (1990) ("[T]he brunt of the Commission's effort fell upon the same businesses Congress sought to protect.").

71 Antitrust Modernization Comm'n, supra note 56, at 316.

72 Decision and Order, McCormick \& Co., FTC Docket No. C-3939 (May 2, 2000). The DOJ ceded all Robinson-Patman enforcement to the FTC in the 1970s. See Thomas E. Kauper, The Justice Department and the Antitrust Laws: Law Enforcer or Regulator?, 35 AnTITRust Bull. 83, 99 (1990) ("[The DOJ] used its understanding with the FTC that the latter would be responsible for government enforcement of the Robinson-Patman Act to avoid any involvement under a statute it thought economically unwise.”). 
Justice unilaterally refused to enforce Robinson-Patman and advocated for its repeal. ${ }^{73}$ This constitutes a fundamental structural shift. ${ }^{74}$

The empirical scholarship on private Robinson-Patman decided cases shows a significant shift in its use within the United States. ${ }^{75}$ One study that collects 28 years of data from private Robinson-Patman decided cases finds a shift in case frequency and in outcome starting in $1982 .{ }^{76}$ From 1982 to 1993 (up through Brooke Group), private plaintiffs were successful in 35 percent of decided cases. ${ }^{77}$ In sharp contrast, in the 2006-2010 period (post-Volvo) the success rate for plaintiffs decreased to less than 5 percent of the time in the 47 decided cases; none of those successes were in primary line Robinson-Patman cases. ${ }^{78}$

If the decided cases are the close cases and/or they shape future business behavior, this suggests that businesses have taken a more aggressive stance regarding price discrimination than they did at the time of The Antitrust Para$d o x$. This outcome may signal a shift to a pricing policy position risk assessment of antitrust risk for Robinson-Patman that is closer to an outcome of per se legality (or at the least presumptively legal), with a negative presumption only in outlier cases. ${ }^{79}$

\section{CONCLUSION}

Robert Bork's writing had a tremendous impact on the antitrust agencies' enforcement policies and court decisions. ${ }^{80}$ Through elegant language, crafty arguments, and good timing, Bork shifted standards of review for common

\footnotetext{
73 Attorney General's Report, supra note 56.

${ }^{74}$ Not all of the reasons behind FTC enforcement activity numbers can be attributed to the agency's understanding of the economic irrationality of the Robinson-Patman Act. FTC priorities shifted during this time. The FTC looked for big cases starting in the 1970s and big cases "found" the FTC as firms filed mergers under Hart-Scott-Rodino. William E. Kovacic, Politics and Partisanship in U.S. Federal Antitrust Enforcement, 79 Antitrust L.J. 687 (2014).

${ }^{75}$ First, a few caveats. Decided cases do not examine all cases filed nor do they examine settlements between parties. However, the nature of the shift in the law affects settlement leverage as only those cases that are uncertain are likely to be litigated. George L. Priest \& Benjamin Klein, The Selection of Disputes for Litigation, 13 J. Legal Stud. 1, 15-17 (1984). Moreover, we cannot know what business practices have not been adopted due to vertical restrictions as well as potential antitrust liability due to mixed horizontal and vertical restraints.

${ }^{76}$ Ryan Luchs et al., The End of the Robinson-Patman Act? Evidence from Legal Case Data, 56 Mgmt. ScI. 2123 (2010).

${ }^{77} \mathrm{Id}$. at 2124.

${ }^{78} \mathrm{Id}$.

${ }^{79}$ Beech-Nut Nutrition Corp. v. Gerber Prods. Co., 69 F. App'x 350 (9th Cir. 2003) (finding that Beech-Nut was able to properly state a claim for a case of below-cost predation); Wiegand Mack Sales \& Serv., Inc. v. Mack Trucks, Inc., 2006 WL 847557, at 1-2 (E.D. Pa. 2006) (distinguishing the facts from those of Volvo).

${ }^{80}$ See George L. Priest, The Abiding Influence of The Antitrust Paradox, 31 Harv. J.L. \& Pub. Pol'y 455 (2008).
} 
vertical restraints from per se illegality to a rule of reason. As shown, in practice, rule of reason treatment makes a number of these practices presumptively legal. This presumptively legal rule of reason in combination with procedural rules that benefit defendants brings certain antitrust conduct closer to Bork's stated goal of per se legality for vertical restraints. It remains to be seen if, with more time, the Bork revolution will become complete with per se illegality eliminated for all but naked cartels and replaced with de facto presumptive legality under the rule of reason or even per se legality. 